Igor Krnetić ${ }^{1}$

Filozofski fakultet

Univerzitet u Banjoj Luci

Republika Srpska, Bosna i Hercegovina

\section{Lana Vujaković}

Filozofski fakultet

Univerzitet u Banjoj Luci

Republika Srpska, Bosna i Hercegovina
UDK 616.89-008.454:159.923.2

Originalni naučni rad

https://doi.org/10.46630/gpsi.18.2021.01

\title{
PSIHOLOŠKA NEFLEKSIBILNOST KAO MEDIJATOR ODNOSA IZMEĐU RANIH MALADAPTIVNIH SHEMA I MANIFESTACIJA DEPRESIVNOSTI, ANKSIOZNOSTI I STRESA
}

\begin{abstract}
Apstrakt
Iako je veza ranih maladaptivnih shema i brojnih psihopatoloških ispoljavanja potvrđena, i dalje ne postoji dovoljan broj istraživanja koja ispituju mehanizme preko kojih se ona ostvaruje. Cilj studije je bio ispitati da li je psihološka nefleksibilnost medijator odnosa između ranih maladaptivnih shema grupisanih $\mathrm{u}$ shema domene $\mathrm{i}$ problema u sadašnjem funkcionisanju, koji se očituju kroz manifestacije depresivnosti, anksioznosti i stresa. Od instrumenata su korišteni Jangov upitnik ranih maladaptivnih shema, Upitnik prihvatanja i akcije i Skala depresivnosti, anksioznosti i stresa. Uzorak je činilo 320 ispitanika $\left(N_{\text {žna }}=215 ; M=33.5 ; S D=9.6\right)$. Rezultati ukazuju na značajne veze psihološke nefleksibilnosti sa svim shema domenima i depresivnim, anksioznim i stresnim ispoljavanjima, a najjača veza je ona ostvarena sa depresivnošću $(r=.74, p$ $<.01)$ i shema domenom oštećenje autonomije $(r=.74, p<.01)$. Psihološka nefleksibilnost se pokazala kao djelimični medijator svih relacija između svih shema domena i manifestacija depresivnosti, anksioznosti i stresa. Iako shema domeni i dalje ostvaruju značajan direktan efekat na psihopatološka ispoljavanja, u slučaju domena oštećenje granica kod anksioznosti $(b=.05, \mathrm{p}<.05,95 \%$ BCa CI $[.03, .05])$ i depresivnosti $(b=$ $.06, \mathrm{p}<.05,95 \%$ BCa CI $[.04, .07])$, najveća je razlika u odnosu na direktni ostvaren efekat, dok je u slučaju stresa najveća razlika u korist indirektnog efekta ostvarena u sklopu domena oštećenje autonomije ( $b=.07, \mathrm{p}<.05,95 \%$ BCa CI $[.05, .08])$. U radu su razmatrane implikacije koje proizilaze iz rezultata, a značajne su za integraciju shema terapije i terapija trećeg talasa.
\end{abstract}

Ključne riječi: rane maladaptivne sheme, shema domeni, psihološka nefleksibilnost, depresivnost, stres, anksioznost

\footnotetext{
${ }^{1}$ igor.krnetic@ff.unibl.org

Citirati rad na sledeći način: Krnetić, I. i Vukajović, L. (2021). Psihološka nefleksibilnost kao medijator odnosa između ranih maladaptivnih shema i manifestacija depresivnosti, anksioznosti i stresa. Godišnjak za psihologiju, 18, 09-25. https://doi.org/10.46630/gpsi.18.2021.01
} 


\section{Uvod}

Veza između ranih maladaptivnih shema i depresivnih, stresnih i anksioznih ispoljavanja je potvrđena kroz mnoga istraživanja (Camara \& Calvette, 2012; Cormier et al., 2011; Delattre et al., 2004; Dozois, 2007). Ipak, sama priroda odnosa je komplikovana i obuhvata širok razvojni period u toku kojeg stičemo različite sposobnosti i formiramo načine prevazilaženja poteškoća. Jedna od takvih sposobnosti bi mogla da bude i psihološka fleksibilnost, čiji se model i efikasnost predstavljaju kroz bihejvioralne terapije trećeg talasa, ali koja je i dalje nedovoljno istražena. Ovaj rad ima za cilj da poveže ove konstrukte i provjeri da li je psihološka (ne)fleksibilnost mehanizam preko kojeg rana iskustva utiču na sadašnjost, a sa čijim razvojem raste i optimizam da naše rane godine razvoja i iskustva ne moraju nužno da diktiraju obrasce ponašanja danas.

\section{Rane maladaptivne sheme (RMŠ)}

Jang (Young, 1990, 1993) formuliše Teoriju ranih maladaptivnih shema, definišući sheme kao najdublji nivo kognicija, široke i stalno prisutne obrasce razmišljanja, koji vode u začarani krug maladaptivnih ispoljavanja. Sheme čine srž selfkoncepta i utiču na naše opažanje svijeta i ljudi. Ovakvi obrasci razmišljanja nastaju u ranom djetinjstvu, u kontaktu sa važnim osobama koje nisu u stanju da zadovolje širok spektar emocionalnih potreba djeteta, od one za bezbjednošću do potrebe za okruženjem koje postavlja realistične granice (Mirović, 2015).

U zavisnosti od toga koja emocionalna potreba nije zadovoljena u djetinjstvu, Džefri Jang i saradnici (Young et al., 2003) sistematizuju osamnaest podtipova shema. Shema domenima nazivaju šire kategorije unutar kojih se nalaze grupisane sheme koje povezuje sličnost razvojnih iskustava i problem sa određenim domenom funkcionisanja (Mirović, 2010). Prvi shema domen, koji obuhvata sheme emocionalne deprivacije, napuštanja i nepovjerenja, defektnosti i socijalne izolacije, naziva se domenom odsustvo povezanosti i odbacivanja, a karakteriše pojedince koji imaju očekivanja da njihove potrebe za sigurnošću i povezanošću sa drugima neće biti zadovoljene. Domen oštećenje autonomije i izvođenja, koji uključuje sheme zavisnost, vulnerabilnost na povredu, neuspjeh i umreženost, podrazumijeva one koji imaju doživljaj da se ne mogu odvojiti ili funkcionisati nezavisno od drugih. Domen oštećenje granica, sa shemama privilegovanost i nedovoljna samokontrola, karakteriše osobe koje nisu razvile adekvatne unutrašnje granice u pogledu reciprociteta i samodiscipline. Domen usmjerenost na druge, obuhvata sheme podređivanja, samožrtvovanja i traženje priznanja/ potvrde, a uključuje pojedince koji veliku vrijednost pridaju zadovoljavanju potreba drugih. Na kraju, peti domen, pretjerana opreznost i inhibicija, uključuje sheme negativizam/pesimizam, nepopustljivi standardi, emocionalna inhibiranost, sklonost kažnjavanju i podrazumijeva pojedince koji prate svoja vrlo često rigidna internalizovana pravila i stavljaju pretjeran fokus na potiskivanje spontanih osjećanja i impulsa.

Kao rezultat prisustva ovakvih kognitivnih tema, dijete razvija određene obrasce ponašanja koja za cilj imaju adaptiranje na shemu i izbjegavanje neprijatnih 
emocija koje iz shema proizilaze (Mirović, 2015). Jang i sar. (Young et al. 2003) ove stilove dijele na: predaja shemi, izbjegavanje sheme i kompenzacija.

\section{Psihološka fleksibilnost (PF)}

Psihološka fleksibilnosti predstavlja konstrukt koji se definiše u sklopu Terapije prihvatanjem i posvećenošću, koja pripada trećem talasu bihejvioralnih terapija. Odnosi se na sposobnost da se potpuno doživi sadašnji trenutak, prihvate sopstvene misli i osjećanja, bez potiskivanja i izbjegavanja, a istovremeno praktikuju ponašanja koja su u skladu sa vrijednostima pojedinca (Hayes et al., 2006; McCracken \& Gauntlett-Gilbert, 2011). Jedan od ciljeva terapije je povećanje psihološke fleksibilnosti, prihvatanje svojih misli i osjećanja takvih kakvi jesu, povezivanje sa sadašnjim trenutkom i promjena ponašanja ili istrajavanje u ponašanjima koja su u skladu sa vrijednostima, a vode ispunjenom životu (Ciarrochi et al., 2010; Hayes et al., 1999; Wersebe et al., 2018). Ovaj model podstiče ljude na ponašanja koja će pratiti individualne vrijednosti, bez obzira na misli, emocije, tjelesne senzacije i druga iskustva koja se mogu osjetiti (Levin et al., 2016).

Osobe sa izraženom visokom psihološkom fleksibilnošću mogu da se prilagode različitim životnim situacijama, da mijenjaju ponašanja koja im nisu od koristi i održavaju ona ponašanja koja ih vode ka vrijednostima čak i kada postoje psihološke barijere kao što su strah, nedostatak samopouzdanja ili ljutnja (Hayes et al., 2006; Levin et al., 2016). Takve osobe će prije biti u stanju da prihvate averzivna unutrašnja iskustva u sadašnjem trenutku koja mogu biti pokrenutna aktiviranjem ranih maladaptivnih shema, istovremeno održavajući željena ponašanja, tj. radeći ono što je zaista važno. Suprotno ovome, psihološka nefleksibilnost predstavlja dominaciju teških unutrašnjih sadržaja (misli, slika, sjećanja, emocija i senzacija) nad ponašanjem koje je u skladu sa vrijednostima pojedinca (Hayes et al., 2004), što vodi daljem izbjegavanju ovakvih sadržaja, pokušajima kontrole, sužavanju raspona ponašanja i sve manjem prisustvu u sadašnjosti. Isti autori navode da se ovakav pristup unutrašnjim iskustvima smatra mehanizmom nastanka psihičkih smetnji.

Danas znamo da je niža psihološka fleksibilnost povezana sa većim stepenom somatizacije, depresivnošću, anksioznošću i generalnim psihološkim distresom (Camara \& Calvette, 2012; Cormier et al, 2011; Delattre et al., 2004; Dozois, 2007; Masuda \& Tully, 2012), dok je viša psihološka fleksibilnost povezana sa samosaosjećanjem, zadovoljstvom na poslu i performansama, kao i generalnim blagostanjem (Bond et al., 2006; Kashdan \& Rottenberg, 2010; Yadavaia et al., 2014);

\section{Rane maladaptivne sheme i psihološka fleksibilnost}

Sve se češće istraživači posvećuju integraciji kostrukata iz Terapije prihvatanjem i posvećenošću i Shema terapije (Roadiger et al., 2018), što je, imajući na umu njihovo djelimično zajedničko porijeklo u teorijama učenja, u potpunosti smisleno. Čini se da konstrukti poput psihološke fleksibilnosti i ranih maladaptivnih shema imaju zajedničku kariku, značaj uticaja bliskih osoba, na razvoj (Fischer et al., 2016). Tako danas imamo podatke da autoritativni stil roditeljstva spriječava razvoj 
psihološke fleksibilnosti, dok ga demokratski promoviše (Williams et al., 2012), te da je dispozicionalna vještina pune svjesnosti, koja je u srcu psihološke fleksibilnosti, $u$ vezi sa prisustvom sigurnog obrasca afektivne vezanosti (Pepping \& Duvenage, 2016).

U istraživanjima koja za cilj imaju dodatno približavanje ova dva pravca, ispitane su relacije između psihološke fleksibilnosti, ranih maladaptivnih shema i psihopatoloških ispoljavanja. Tako Fišer i sar. (Fischer et al., 2016) dobijaju rezultate koji ukazuju na to da psihološka fleksibilnost predstavlja medijator odnosa ranih maladaptivnih shema i psihopatoloških ispoljavanja u vidu depresivnosti, anksioznosti i stresa. Baf i sar. (Baugh et al., 2019) zaključuju da je psihološka fleksibilnost najsnažniji medijator između ranog emocionalnog zanemarivanja u djetinjstvu i povjerenja u partnera, čak snažniji od ranih maladaptivnih shema, dok se medijatorska uloga psihološke fleksibilnosti u odnosu između shema domena odsustva povezanosti i depresivnosti takođe potvrđuje (Rezaei \& Ghazanfari, 2016). Kada je u pitanju manifestacija anksioznosti, potvrđena je medijatoska uloga psihološke nefleksibilnosti između shema domena odsustvo povezanosti i odbacivanje, oštećenje autonomije i izvođenja, pretjerana opreznost i inhibicija i anksioznih simptoma (Borjali et al., 2016), što ukazuje na važnost razvijanja tehnika za povećanje psihološke fleksibilnosti u cilju potencijalne redukcije psihopatoloških ispoljavanja u budućnosti. U tom smislu, Redinger i sar. (2018) govore o sveobuhvatnom pristupu - Kontekstualnoj shema terapiji, koji inkorporira bazične ideje Terapije prihvatanjem i posvećenosti u Shema terapiju na praktičnom nivou, kroz procese prihvatanja, pune svjesnosti sada i ovdje i samosaosjećanja. Naglasak u terapiji se tiče povećanja svjesnosti o sadržaju ranih maladaptivnih shema, kao i nezdravih mehanizama prevladavanja sheme, dok se kroz dodatak u vidu tehnika iz terapija trećeg talasa kognitivno-bihejvioralne terapije, radi se na građenju modaliteta zdravog odraslog.

Iako se sve više priča o približavanju ova dva konstrukta, i na teorijskom i na praktičnom nivou, relacije i mehanizmi povezanosti psihološke (ne)fleksibilnosti u okviru specifičnih domena ranih maladaptivnih shema i dalje nisu dovoljno istraženi. Takođe, koliko je autorima ovog istraživanja poznato, relacije između ranih maladaptivnih shema i psihološke nefleksibilnosti u kontekstu sadašnjih ispoljavanja na uzorcima iz Srbije, Hrvatske i Bosne i Hercegovine do sada nisu ispitane, tako da je primarni cilj ovog istraživanja provjeriti postoji li medijatorska uloga psihološke nefleksibilnosti između različitih shema domena i sadašnjih depresivnih, anksioznih i stresnih manifestacija. Uzimajući u obzir rezultate prethodnih istraživanja na stranim uzorcima, autori ove studije očekuju da će se psihološka nefleksibilnost pokazati kao parcijalni medijator odnosa između shema domena i kriterijumskih varijabli u istraživanju. Ako bi se ova hipoteza potvrdila, praktične implikacije ovog istraživanja bi još jednom ukazale na značaj razvoja psihološke fleksibilnosti u kontekstu umanjenja efekata ranih neadekvatnih iskustava, ali i potvrdile i opravdale potrebu za integracijom shema terapije sa terapijama iz trećeg talasa kognitivno-bihejviralnog domena. 


\section{Metod}

\section{Ispitanici}

Ukupni uzorak je podrazumijevao 320 ispitanika $\left(N_{\text {žene }}=215\right)$, starosti između 19 i $62(M=33.5 ; S D=9.6)$ godine. Svi učesnici u ispitivanju dolaze sa teritorije Bosne i Hercegovine, a podaci u vidu samoprocjena su prikupljeni putem online baterije. Učešće u istraživanju je bilo dobrovoljno i anonimno.

\section{Instrumenti}

Skala depresivnosti, anksioznosti i stresa (Depression Anxiety and Stress Scales, DASS-21, Lovibond \& Lovibond, 1995, za srpsku adaptaciju vidjeti Jovanović i sar., 2011) — za mjerenje depresivnih, anksioznih i stresnih ispoljavanja iskorištena je DASS-21 skala, koja se sastoji od 21 ajtema, od kojih po sedam mjere depresivnost, anksioznost i stres. Ispitanici odgovaraju na Likertovoj skali od 4 stepena (od 1 = nimalo, do $4=$ gotovo stalno). Veći skorovi ukazuju na veća ispoljavanja određenog tipa simptoma. Kronbahovi alfa koeficijenti pouzdanosti skala su zadovoljavajući (od .825 za anksioznost do .882 za depresivnost).

Upitnik prihvatanja i akcije (AAQ-II; Bond et al., 2011, za srpsku adaptaciju vidjeti Žuljević et al., 2020) je iskorišten kao mjera psihološke fleksibilnosti. Kraća verzija upitnika se sastoji od sedam, negativno okrenutih, tvrdnji, koje ispitanik procjenjuje na sedmostepenoj skali Likertovog tipa ( od $1=$ nikada, do $7=u v i j e k$ ). Maksimalan rezultat na upitniku je 49, pri čemu veći rezultat ukazuje na veću psihološku nefleksibilnost, a niži na psihološku fleksibilnost. Kronbahov alfa koeficijent pouzdanosti je .922 .

Jangov upitnik ranih maladaptivnih shema - kraća forma (YSQ-S3; Young \& Brown, 2005, srpski prevod korišten u Mirović \& Mešković, 2017) — ispoljavanja u okviru djelovanja ranih maladaptivnih shema ispitana su skraćenom verzijom upitnika od 90 tvrdnji. Ajtemi mjere 18 ranih maladaptivnih shema, a svaka shema se odnosi na po pet stavki. Ispitanik odgovara na Likertovoj skali šestostepenog tipa (od $1=$ potpuno netačno, do 6 = potpuno tačno). Veći skor na pojedinim skalama upućuje na veću izraženost konkretne sheme. Sabirajući skorove na pojedinačnim shemama koje sačinjavaju jedan domen, a uzimajući u obzir broj tih shema, dobijaju se prosječni skorovi za pet shema domena (odsustvo povezanosti i odbacivanje, oštećenje autonomije i izvođenja, oštećenje granica, usmjerenost na druge i pretjerana opreznost i inhibicija).

\section{Statistička obrada}

U nastojanju da se ispitaju odnosi između ranih maladaptivnih shema, psihološke nefleksibilnosti i manifestacija depresivnosti, anksioznosti i stresa sprovedene su korelaciona, regresiona i medijaciona analiza. U poziciji prediktorskih varijabli postavljeni su domeni ranih maladaptivnih shema, a u poziciji kriterijumskih varijabli manifestacije depresivnosti, anksioznosti i stresa. U medijacionoj analizi, u poziciji medijatora postavljena je psihološka nefleksibilnost. Sve analize su odrađene 
u IBM SPSS21 statističkom paketu, uz nadogradnju The PROCESS macro ekstenzijom za medijacionu analizu. Broj simulacionih uzoraka je iznosio 5000.

\section{Rezultati}

\section{Deskriptivna statistika}

U Tabeli 1 prikazani su deskriptivni statistički pokazatelji svih varijabli korištenih u istraživanju. Skjunis i kurtozis vrijednosti upućuju na normalnu raspodjelu rezultata. Kronbah koeficijenti pouzdanosti upućuju na zadovoljavajuće vrijednosti kada su u pitanju psihološka nefleksibilnost i kriterijumske varijable, dok se u okviru shema domena pouzdanost kreće od .57 (domen oštećenje granica) do .87 (domen odsustvo povezanosti i odbacivanja). Ako znamo da domen oštećenje granica sačinjavaju sheme Privilegovanost i Nedovoljna samokontrola, sheme koje prema teoriji možda veže sličnost ranih iskustava, ali koje mogu imati različite manifestacije, ne čudi nešto niža pouzdanost.

\section{Tabela 1}

Deskriptivni statistički pokazatelji varijabli korištenih u istraživanju

\begin{tabular}{lllllllll}
\hline & Raspon & \multicolumn{1}{c}{$M$} & \multicolumn{1}{c}{$S D$} & \multicolumn{1}{c}{$S k$} & \multicolumn{1}{c}{$S E$} & \multicolumn{1}{c}{ Ku } & \multicolumn{1}{c}{$S E$} & $\alpha$ \\
\hline PN & $1-7$ & 2.86 & 1.54 & 0.79 & 0.14 & -0.19 & 0.27 & .92 \\
DEP & $1-4$ & 1.72 & 0.71 & 1.12 & 0.14 & 0.49 & 0.27 & .88 \\
S & $1-4$ & 2.26 & 0.75 & 0.41 & 0.14 & -0.62 & 0.27 & .88 \\
ANX & $1-4$ & 1.69 & 0.62 & 1.32 & 0.14 & 1.44 & 0.27 & .82 \\
DOP & $5-29.2$ & 11.00 & 4.79 & 1.25 & 0.14 & 1.61 & 0.27 & .87 \\
DOA & $5-27$ & 9.79 & 4.21 & 1.38 & 0.14 & 1.88 & 0.27 & .83 \\
DOG & $5-26.5$ & 15.5 & 4.27 & 0.00 & 0.14 & -0.47 & 0.27 & .57 \\
DUND & $5-26$ & 13.8 & 4.44 & 0.48 & 0.14 & -0.08 & 0.27 & .67 \\
DOII & $5-27$ & 13.9 & 4.42 & 0.48 & 0.14 & 0.13 & 0.27 & .78 \\
\hline
\end{tabular}

Napomena $: \mathrm{PN}=$ psihološka nefleksibilnost; DEP = depresivnost; $\mathrm{ANX}=$ anksioznost; $\mathrm{S}=$ stres; DOP = domen odsustva povezanosti i odbacivanja; DOA = domen oštećenje autonomije i izvođenja; DOG = domen oštećenja granica; DUND = domen usmjerenosti na druge; DOII = domen pretjerana opreznost i inhibicija; $M=$ aritmetička sredina; $S D=$ standardna devijacija; $M i n=$ najmanja vrednost; $M a x=$ najveća vrednost; $S k=$ skjunes; $K u=$ kurtozis; $S E=$ standardna greška; $\alpha=$ pouzdanost mere.

\section{Korelaciona i regresiona analiza}

U Tabeli 2 prikazana je korelacijska analiza varijabli korištenih u istraživanju. Sve ispitane korelacije su značajne, $s$ tim da je najviša ostvarena veza psihološke nefleksibilnosti ona sa depresivnošću, odnosno domenom oštećenje autonomije i izvođenja. Manifestacije depresivnosti, anksioznosti i stresa ostvaruju sve značajne veze sa shema domenima, s tim da je ona najizraženija veza između manifestacija depresivnosti i shema domena odsustvo povezanosti i odbacivanje. 
Tabela 2

Korelacijska analiza

\begin{tabular}{llllllllll}
\hline & PN & DEP & S & ANX & DOP & DOG & DOA & DUND & DOII \\
\hline PN & - & & & & & & & & \\
DEP & $.74 * *$ & - & & & & & & \\
S & $.63 * *$ & $.70^{* *}$ & - & & & & & \\
ANX & $.64 * *$ & $.71 * *$ & $.64 * *$ & - & & & & \\
DOP & $.73 * *$ & $.75 * *$ & $.59 * *$ & $.59 * *$ & - & & & \\
DOG & $.52 * *$ & $.51 * *$ & $.50 * *$ & $.46^{* *}$ & $.57 * *$ & - & & \\
DOA & $.74 * *$ & $.71 * *$ & $.55^{* *}$ & $.59 * *$ & $.79 * *$ & $.57 * *$ & - & & \\
DUND & $.67 * *$ & $.62 * *$ & $.57 * *$ & $.56 * *$ & $.75 * *$ & $.67^{* *}$ & $.72 * *$ & - & \\
DOII & $.66^{* *}$ & $.64 * *$ & $.60 * *$ & $.56 * *$ & $.79 * *$ & $.61 * *$ & $.72 * *$ & $.74 * *$ & - \\
\hline
\end{tabular}

Napomena. ${ }^{* *} p<.01$. PN = psihološka nefleksibilnost; DEP = depresivnost; ANX $=$ anksioznost; $\mathrm{S}=$ stres; DOP = domen odsustva povezanosti i odbacivanja; DOA = domen oštećenje autonomije i izvođenja; $\mathrm{DOG}=$ domen oštećenja granica; DUND = domen usmjerenosti na druge; DOII = domen pretjerane opreznosti i inhibicija.

U Tabeli 3 prikazani su i regresioni koeficijenti modela koji kao prediktore imaju shema domene a kriterijumske varijable manifestacije depresivnosti, anksioznosti i stresa. Na osnovu rezultata, možemo da vidimo da su shema domeni značajni prediktori svih kriterijumskih varijabli, pri čemu je procenat objašnjene varijanse, čak 61\% najveći u slučaju manifestacije depresivne simptomatologije. Prediktor sa najvišim parcijalnim doprinosom depresivnog ispoljavanja je shema domen odsustvo povezanosti i odbacivanje, anksioznosti shema domen oštećenje autonomije i izvođenja, dok je najbolji prediktor stresa shema domen pretjerana opreznost $\mathrm{i}$ inhibicija.

Tabela 3

Karakteristike modela koji predviđaju depresivnost, anksioznost $i$ stres

\begin{tabular}{|c|c|c|c|c|c|c|c|}
\hline Kriterijum & $R$ & $R^{2}$ & $F(d f)$ & $p$ & $\begin{array}{l}\text { Shema } \\
\text { domen }\end{array}$ & $\beta$ & $p$ \\
\hline \multirow[t]{5}{*}{ DEP } & .78 & .61 & $96.51(5,314)$ & .00 & DOP & .45 & .00 \\
\hline & & & & & DOG & .06 & .20 \\
\hline & & & & & DOA & .30 & .00 \\
\hline & & & & & DUND & .02 & .79 \\
\hline & & & & & DOII & .02 & .74 \\
\hline \multirow[t]{5}{*}{ ANX } & .64 & .41 & $44.2(5,314)$ & .00 & DOP & .20 & .02 \\
\hline & & & & & DOG & .08 & .17 \\
\hline & & & & & DOA & .23 & .00 \\
\hline & & & & & DUND & .12 & .10 \\
\hline & & & & & DOII & .10 & .21 \\
\hline S & .65 & .42 & $46.28(5,314)$ & .00 & DOP & .15 & .07 \\
\hline
\end{tabular}




\begin{tabular}{lccc}
\hline & & \\
& DOG & .13 & .02 \\
DOA & .09 & .23 \\
DUND & .16 & .03 \\
& DOII & .22 & .00 \\
\hline
\end{tabular}

Napomena. DEP = depresivnost; ANX = anksioznost; $\mathrm{S}=$ stres; DOP = domen odsustva povezanosti i odbacivanja; DOA = domen oštećenja autonomije i izvođenja; DOG $=$ domen oštećenja granica; DUND $=$ domen usmjerenosti na druge; DOII $=$ domen pretjerane opreznosti i inhibicija; $\beta=$ standardizovani regresioni koeficijent; $R=$ koeficijent multiple korelacije; $R^{2}=$ koeficijent determinacije; $F=$ F statistik.

\section{Medijaciona analiza}

U medijatorskoj analizi u poziciju medijatora smo postavili psihološku nefleksibilnost, tako da je s obzirom na 5 prediktorskih varijabli i 3 kriterijumske ukupno odrađeno 15 medijatorskih analiza.

Tabela 4

Psihološka nefleksibilnost kao medijator između shema domena i depresivnosti

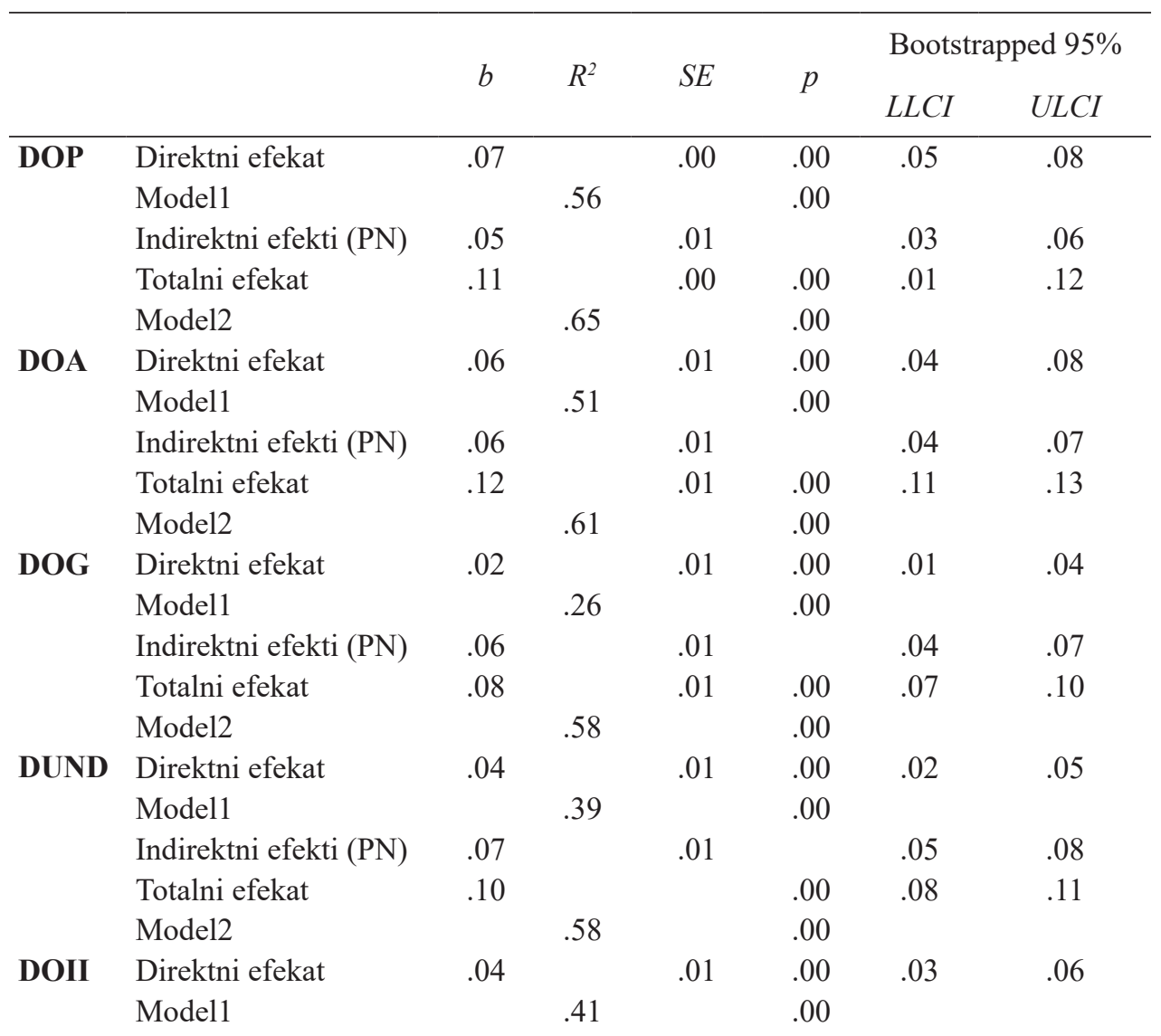




\begin{tabular}{|c|c|c|c|c|}
\hline Indirektni efekti (PN) & .06 & .01 & & .05 \\
\hline Totalni efekat & .10 & .01 & .00 & .09 \\
\hline Model2 & & & .00 & \\
\hline
\end{tabular}

Napomena. Model 1 = sam domen; Model 2 = domen + psihološka nefleksibilnost; $\mathrm{DOP}=$ domen odsustva povezanosti i odbacivanja; DOA = domen oštećenja autonomije i izvođenja; DOG = domen oštećenja granica; DUND = domen usmjerenosti na druge; DOII = domen pretjerane opreznosti i inhibicija; $\beta=$ standardizovani regresioni koeficijent; $R=$ koeficijent multiple korelacije; $R^{2}=$ koeficijent determinacije; $S E=$ standardna greška; LLCI = donja granica intervala povjerenja; ULCI = gornja granica intervala povjerenja.

Psihološka nefleksibilnost predstavlja značajan medijator između svih shema domena i depresivnosti. Model koji objašnjava najveći procenat varijanse je model koji sadrži domen odsustva povjerenja i psihološku nefleksibilnost $\left(R^{2}=.65, p<\right.$ .001). Najveći samostalni i direktni efekat jednog domena na manifestacije depresivnosti je model koji sadrži domen odsustvo povezanosti i odbacivanje $(b=.07, \mathrm{p}$ $<.001$ ), dok je u okviru modela koji sadrži domen oštećenja granica najizraženija razlika između direktnog i indirektnog efekta ostvarena preko medijatora psihološke nefleksibilnosti. U kontekstu domena oštećenje autonomije i izvođenje skoro je podjednak efekat na depresivnost ostvaren direktno i preko medijatora. Kada je u pitanju model koji sadrži domen usmjerenosti na druge, i ovdje je većina efekta na depresivnost ostvarena preko psihološke nefleksibilnosti $(b=.06 ; 95 \%$ BCa CI $[.05$, .08]), dok je u modelu koji sadrži domen pretjeranog opreza i inhibicije takođe većina efekta na depresivnost ostvarena preko psihološke nefleksibilnosti $(b=.06 ; 95 \%$ $\mathrm{BCa}$ CI $[.05, .07])$.

\section{Tabela 5}

Psihološka nefleksibilnost kao medijator između shema domena i anksioznosti

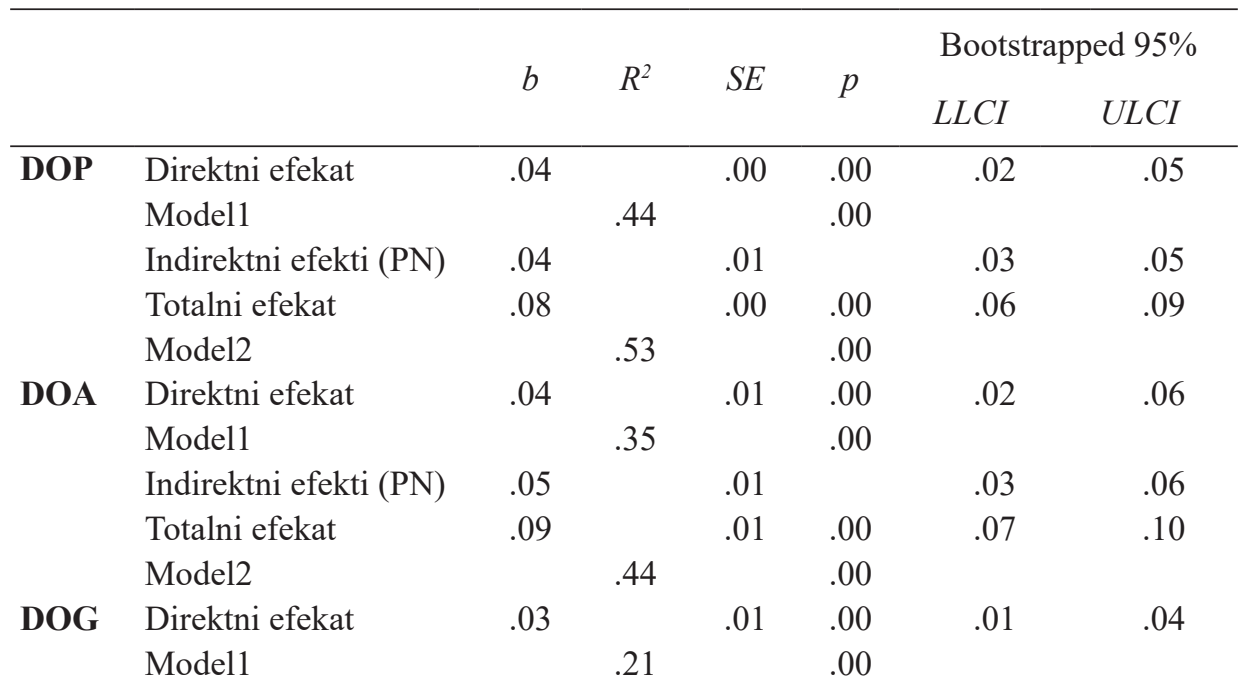




\begin{tabular}{|c|c|c|c|c|c|c|c|}
\hline & Indirektni efekti (PN) & .05 & & .01 & & .03 & .05 \\
\hline & Totalni efekat & .07 & & .01 & .00 & .05 & .08 \\
\hline & Model2 & & .43 & & .00 & & \\
\hline \multirow[t]{5}{*}{ DUND } & Direktni efekat & .04 & & .01 & .00 & .02 & .05 \\
\hline & Model1 & & .31 & & .00 & & \\
\hline & Indirektni efekti (PN) & .05 & & .01 & & .03 & .06 \\
\hline & Totalni efekat & .08 & & .01 & .00 & .06 & .09 \\
\hline & Model2 & & .43 & & .00 & & \\
\hline \multirow[t]{5}{*}{ DOII } & Direktni efekat & .04 & & .01 & .00 & .02 & .05 \\
\hline & Model1 & & .31 & & .00 & & \\
\hline & Indirektni efekti (PN) & .05 & & .01 & & .03 & .06 \\
\hline & Totalni efekat & .08 & & .01 & .00 & .06 & .09 \\
\hline & Model2 & & .44 & & .00 & & \\
\hline
\end{tabular}

Napomena. Model 1 = sam domen; Model $2=$ domen + psihološka nefleksibilnost. $\mathrm{DOP}=$ domen odsustva povezanosti i odbacivanje; DOA $=$ domen oštećenja autonomije i izvođenja; DOG = domen oštećenja granica; DUND = domen usmjerenosti na druge; DOII $=$ domen pretjerana opreznost $\mathrm{i}$ inhibicija; $\beta=$ standardizovani regresioni koeficijent; $R=$ koeficijent multiple korelacije; $R^{2}=$ koeficijent determinacije; $S E=$ standardna greška; LLCI = donja granica intervala povjerenja; ULCI = gornja granica intervala povjerenja.

Psihološka nefleksibilnost predstavlja značajan medijator između svih shema domena i anksioznosti. U odnosu na pet shema domena, model koji objašnjava najveći procenat varijanse je opet model koji sadrži domen odsustvo povezanosti i odbacivanje i psihološku nefleksibilnost $\left(R^{2}=.53, p<.001\right)$. Jedino u modelu koji sadrži domen odsustvo povezanosti i odbacivanje podjednak efekat prediktor ostvaruje direktno i preko psihološke nefleksibilnosti, dok je svim drugim modelima većina efekta prediktora ostvarena preko medijatora. Konkretno, najveća razlika između indirektnog i direktnog efekta, $\mathrm{u}$ korist medijatora je ostvarena u kontekstu domena oštećenje granica $(b=.05 ; 95 \%$ BCa CI $[.03, .05])$.

\section{Tabela 6}

Psihološka nefleksibilnost kao medijator između shema domena i stresa

\begin{tabular}{llcccccc}
\hline & & & & & \multicolumn{2}{c}{ Bootstrapped 95\% } \\
& & $b$ & $R^{2}$ & $S E$ & $p$ & & \\
& & & & & $L L C I$ & $U L C I$ \\
\hline DOP & Direktni efekat & .04 & & .01 & .00 & .02 & .06 \\
\hline & Model1 & & .34 & & .00 & & \\
& Indirektni efekti (PN) & .05 & & .01 & & .03 & .07 \\
& Totalni efekat & .09 & & .00 & .00 & .08 & .11 \\
& Model2 & & .44 & & .00 & & \\
\hline DOA & Direktni efekat & .03 & & .01 & .00 & .01 & .05
\end{tabular}




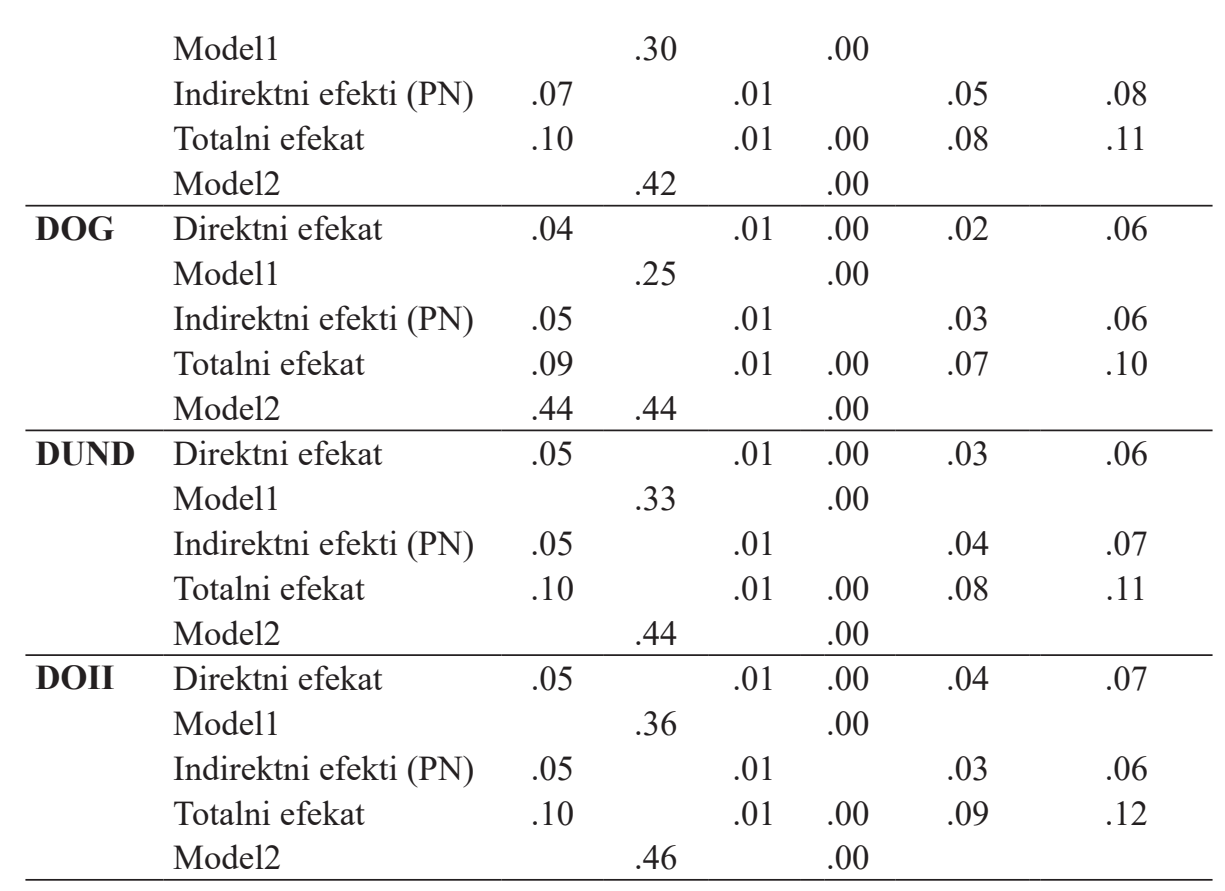

Napomena. Model 1 = sam domen; Model 2 = domen + psihološka nefleksibilnost. DOP $=$ domen odsustva povezanosti i odbacivanja; DOA = domen oštećenja autonomije i izvođenja; DOG = domen oštećenja granica; DUND = domen usmjerenosti na druge; DOII $=$ domen pretjerana opreznost $\mathrm{i}$ inhibicija. $\beta=$ standardizovani regresioni koeficijent; $R=$ koeficijent multiple korelacije; $R^{2}=$ koeficijent determinacije; $S E=$ standardna greška; LLCI = donja granica intervala povjerenja; ULCI = gornja granica intervala povjerenja.

Psihološka nefleksibilnost predstavlja značajan medijator između svih shema domena i stresa. Model koji objašnjava najveći procenat varijanse je model koji sadrži domen pretjerani oprez i inhibicija $\left(R^{2}=.46, p<.001\right)$. U modelima koji sadrže domene usmjerenosti na druge i pretjeran oprez i inhibicija skoro podjednak efekat prediktor ostvaruje direktno i preko medijatora, dok je u modelima koji sadrže domen odsustvo povezanosti i odbacivanje, domen oštećenje autonomije i izvođenje i domen oštećenja granica većina efekta prediktora ostvarena preko medijatora. Konkretno, najveći efekat na stresna ispoljavanja preko medijatora je ostvaren u odnosu prediktor domen oštećenje autonomije i izvođenja ( $b=.07 ; 95 \%$ BCa CI $[.05, .08])$.

\section{Diskusija}

Cilj istraživanja je bio ispitati medijatorsku ulogu psihološke nefleksibilnosti u relaciji shema domena i manifestacija depresivnosti, anksioznosti i stresa. U ovom odnosu psihološka fleksibilnost bi mogla da bude određena vrsta spone, mehanizam, čije učenje i uvježbavanje može da promijeni onaj dio efekta koji rane nezadovolje- 
ne emocionalne potrebe ostvaruju na pojedinčevo sadašnje funkcionisanje. Nalazi istraživanja idu u prilog ovoj pretpostavci. Naime, psihološka nefleksibilnost ostvaruje srednje visoku, do visoke pozitivne povezanosti sa svim mjerenim varijablama. U skladu sa prethodnim istraživanjima potvrđuje se snažna veza između psihološke nefleksibilnosti i depresivnih manifestacija (Kato, 2016; Masuda \& Tully, 2012; Masuda et al., 2010). Najveći intenzitet povezanosti psihološke nefleksibilnosti u kontekstu shema domena je veza sa domenom oštećenje autonomije i izvođenja. S obzirom na to da domen oštećenje autonomije i izvođenja podrazumijeva smanjenu nezavisnost u funkcionisanju, niže samopouzdanje i teškoće u odvajanju od drugih, ne čudi da psihološka nefleksibilnost, odnosno nesposobnost prihvatanja sopstvenih unutrašnjih sadržaja i iskustava, predstavlja važan korelat ovakvog doživljaja sebe. Slično nalazima ove studije, u istraživanju Borjali i sar. (2016) dobijene su značajne veze psihološke nefleksibilnosti i svih shema domena, s tim da je najizraženija veza takođe bila u odnosu na domen oštećenja autonomije i izvođenja.

Sve veze između psihopatoloških ispoljavanja i shema domena su takođe značajne i u domenu srednje visokih do visokih korelacija, s tim da je povezanost najizraženija u domenu depresivnih manifestacija. Najbolji prediktor u odnosu na depresivnost je domen odsustvo povezanosti i odbacivanje, odnosno domen oštećenje autonomije i izvođenja u slučaju anksioznosti. U sličnim istraživanjima sheme koje ostvaruju najveću vezu u odnosu na depresivnost i anksioznost su upravo sheme koje pripadaju ovim domenima (Anmuth, 2011). Kada je u pitanju stres, značajni prediktori su preostala tri domena. Možda objašnjenje ovakvih nalaza treba tražiti u samom sadržaju tvrdnji koje se odnose na stres, a koje u velikom postotku podrazumijevaju nisku toleranciju na frustraciju i povećanu razdražljivost,koji su karakteristični za veliki broj shema koje sačinjavaju domen oštećenje granica, ali i domen usmjerenost na druge i domen pretjeran oprez i inhibicija.

Psihološka nefleksibilnost se pokazuje kao značajan medijator između odnosa svih shema domena i svih ispitivanih psihopatoloških manifestacija. Model koji najbolje objašnjava varijansu u depresivnosti jeste model koji sadrži domen odsustvo povezanosti i odbacivanje i psihološku nefleksibilnost. Iako je psihološka nefleksibilnost medijator svih odnosa, domen odsustva povezanosti i odbacivanje i dalje najveći dio svog efekta na depresivnost ostvaruje direktno, dok je u slučaju domena oštećenje granica efekat shema u najvećem procentu indirektan. Kada je u pitanju anksioznost, najveći procenat varijanse takođe objašnjava model koji sadrži domen odsustvo povezanosti i odbacivanje i psihološke nefleksibilnosti. Ono što je ovdje evidentno jeste da ne postoji domen koji direktno ostvaruje viši efekat nego putem medijatora, što je posebno vidljivo u slučaju domena oštećenje granica. Kod stresa najveći procenat objašnjenje varijanse ostvaruje model koji se tiče domena oštećenja granica i psihološka nefleksibilnost. Ni u slučaju stresa ne postoji domen koji direktno ostvaruje veći efekat na doživljaj stresa nego putem medijatora, što je posebno evidentno kod domena oštećenje autonomije i izvođenja.

Dobijeni nalazi su u skladu sa prethodnim istraživanjima, koja ukazuju na medijatorsku ulogu psihološke nefleksibilnosti u odnosu RMŠ i simptoma depresivnosti (Beard, 2019). U istraživanju Borjali i sar. (2016) potvrđena je medijatorska uloga psihološke 
fleksibilnosti između svih shema domena, osim domena usmjerenosti na druge i domena oštećenja granica, i anksioznih simptoma, što je interesantno i donekle kontradiktorno nalazima koje smo mi dobili za varijablu anksioznosti. U odnosima pojedinaca koje karakteriše domen oštećenje granica često može da se prepozna veliki stepen kritičnosti, te često pripisivanje manje prava ili kompetencija, kao i specifičan odnos prema dugoročnim ciljevima (Mirović, 2010). Razvitak psihološke fleksibilnosti, koji u sebe uključuje jasnu svijest o vrijednostima, idejama kakav život osoba želi da živi i prihvatanje, može doprinijeti kako razvijanju samosaosjećanja, tako i razvijanju empatije prema drugima. Samim tim, smisleno je da simptomi anksioznosti koji često proizilaze iz loše organizacije, kritičke nastrojenosti i problema u komunikaciji, pod dejstvom ovog domena, mogu biti redukovani sa razvitkom psihološke fleksibilnosti. Dalje, Tim (Thimm, 2017) dolazi do zaključka da su puna svijest i samosaosjećanje mehanizmi preko kojih RMŠ sheme ostvaruju svoj efekat na doživljaj psihološkog distresa.

Dobijeni nalazi ukazuju da bi sa razvitkom psihološke fleksibilnosti, veliki dio negativnog efekta RMŠ mogao biti neutralisan, pogotovo u odnosu na domen oštećenje granica kada su u pitanju depresivnost i anksioznost, odnosno domen oštećenje autonomije i izvođenja kada je u pitanju stres. Čini se da je smanjenje psihološke fleksibilnosti jedan od mehanizama preko kojih rana iskustva ostvaruju svoj efekat na kasnije manifestacije depresivnosti, anksioznosti i stresa. Implikacije koje proizilaze iz ovakvih nalaza značajne su za psihoterapijsku praksu. Čini se da tehnike koje se koriste, a koje ne uključuju razvoj psihološke fleksibilnosti, nisu dovoljne za klijente sa nezadovoljavajućim ranim iskustvima. Zato su pokušaji shema terapeuta da pored uobičajenih tehnika iz domena shema terapije svakako implementiraju tehnike koje ciljaju na razvijanjepsihološke fleksibilnosti, u pokušaju dalje integracije terapija trećeg talasa kognitivno-bihejvioralne terapije i shema terapije, zaista smisleni i ohrabrujući (Van Vreeswijk et al., 2014). Početni empirijski nalazi su na neki način već implementirani u praksu, kroz kontekstualnu shema terapiju (Roedinger et al., 2018) u sklopu koje su tradicionalne shema tehnike obogaćene tehnikama iz terapije prihvatanjem i posvećenošću, dijalektičke bihejvioralne terapije i terapije usmjerene na saosjećanje, koje potpomažu građenju zdravog odraslog modaliteta.

Na umu treba imati da je u ovom istraživanju ipak korišten mali uzorak, sa većinom ženskih ispitanika. Mjere iskorištene u istraživanju su u osnovi samo-procjene, što predstavlja još jedno ograničenje ovog istraživanja. U pitanju je krossekcijski dizajn istraživanja, koji nam onemogućuje da donosimo kauzalne zaključke. Bilo bi interesantno prikazati kakvi se efekti dobijaju u istoj grupi ispitanika nakon neke vrste treninga psihološke fleksibilnosti, te praćenjem dugoročnijih efekata ovakvih treninga.

\section{Literatura}

Anmuth, L. (2011). Early Maladaptive Schemas and negative life events in the Prediction of depression and anxiety [Master's thesis, Rowan University].Theses and Dissertations. https://rdw.rowan.edu/cgi/viewcontent.cgi?article $=1068 \&$ context $=$ etd 
Baugh, L. M., Cox, D. W., Young, R. A., \& Kealy, D. (2019). Partner trust and childhood emotional maltreatment: The mediating and moderating roles of maladaptive Schemas and psychological flexibility. Journal of Contextual Behavioral Science, 12, 66-73. https://doi.org/10.1016/j.jcbs.2019.02.001

Beard, J. (2019). The Relationship between Early Maladaptive Schemas and Depression: TheMediational Role of Psychological Inflexibility. OSR Journal of Student Research, 5, Article 96. https://scholarworks.lib.csusb.edu/osr/vol5/iss1/96

Bond, F. W., Hayes, S. C., Baer, R. A., Carpenter, K. M., Guenole, N., Orcutt, H. K., Waltz, T., \& Zettle, R. D. (2011). Preliminary psychometric properties of the Acceptance and Action Questionnaire-II: A revised measure of psychological inflexibility and experiential avoidance. Behavior Therapy, 42(4), 676-688. https://doi.org/10.1016/j.beth.2011.03.007

Bond, F. W., Hayes, S. C., \& Barnes-Holmes, D. (2006). Psychological Flexibility, ACT, and Organizational Behavior. Journal of Organizational Behavior Management, 26(1-2), 25-54. https://doi.org/10.1300/J075v26n01_02

Borjali, A., Bahramizadeh, H., Eskandai, H., \&Farrokhi, N. (2016). Psychological flexibility mediate the effect of early maladaptive schemas on Psychopathology. International Journal of Applied Behavioral Sciences, 3(4), 9-17. https://doi.org/10.22037/ ijabs.v3i4.15451

Burke, K., \& Moore, S. (2014). Development of the parental psychological flexibility questionnaire. Child Psychiatry \& Human Development, 46(4), 1-10. https://doi. org/10.1007/s10578-014-0495-X

Cámara, M., \& Calvete, E. (2012). Early maladaptive schemas as moderators of the impact of stressful events on anxiety and depression in university students. Journal of Psychopathology and Behavioral Assessment, 34(1), 58-68. https://doi.org/10.1007/ s10862-011-9261-6

Ciarrochi, J., Bilich, L., \& Godsell, C. (2010). Psychological flexibility as a mechanism of change in acceptance and commitment therapy. In R. A. Baer (Ed.), Assessing mindfulness and acceptance processes in clients: Illuminating the theory and practice of change (pp. 51-75). Context Press/New Harbinger Publications.

Cormier, A., Jourda, B., Laros, C., Walburg, V., \& Callahan, S. (2011). L'influence entre les schémas précoces inadaptés et la dépression [Influence between early maladaptive schemas and depression]. L'Encéphale: Revue de psychiatrie clinique biologique et thérapeutique, 37(4), 293-298. https://doi.org/10.1016/j.encep.2011.01.001

Delattre, V., Servant, D., Rusinek, S., Lorette, C., Parquet, P. J., Goudemand, M., \&Hautekeete, M. (2004). Les schémas précoces dysfonctionnels : étude chez des patients adultes souffrant d'un trouble anxieux [The early maladaptive schemas: a study in adult patients with anxietydisorders]. L'Encéphale: Revue de psychiatrie clinique biologique et thérapeutique,, 30(3), 255-258 . https://doi.org/10.1016/s0013-7006(04)95437-1

Dozois, D. J. A. (2007). Stability of negative self-structures: A longitudinal comparison of depressed, remitted, and nonpsychiatric controls. Journal of Clinical Psychology, 63(4), 319-338. https://doi.org/10.1002/jclp.20349

Fischer, T. D., Smout, M. F., \&Delfabbro, P. H. (2016). The relationship between psychological flexibility, early maladaptive schemas, perceived parenting and psychopathology. Journal of contextual behavioural science, 5(3), 169-177. https://doi.org/10.1016/j.jcbs.2016.06.002 
Hayes, S. C., Luoma, J. B., Bond, F. W., Masuda, A., \& Lillis, J. (2006). Acceptance and commitment therapy: Model, processes and outcomes. Behaviour Research and Therapy, 44(1), 1-25. https://doi.org/10.1016/j.brat.2005.06.006

Hayes, S. C., Strosahl, K. D., Bunting, K., Twohig, M. \& Wilson, K. G. (2004). What is Acceptance and Commitment Therapy? In: S. C. Hayes i K. D. Strosahl (Eds.), A practical guide to Acceptance and Commitment Therapy (3-29). Springer. https:// doi.org/10.1007/978-0-387-23369-7_1

Hayes, S. C., Strosahl, K. D., \& Wilson, K. G. (1999). Acceptance and commitment therapy: An experiential approach to behavior change. Guilford Press.

Jovanović, Žuljević, D. \& Brdarić, D. (2011). Skala depresivnosti, anksioznosti i stresa (DASS-21) — struktura negativnog afekta kod adolescenata. Engrami, 33(2), 19-28.

Kashdan, T. B., \&Rottenberg, J. (2010). Psychological flexibility as a fundamental aspect of health. Clinical Psychology Review, 30(7), 865-878. https://doi.org/10.1016/j. cpr.2010.03.001

Kato T. (2016). Impact of psychological inflexibility on depressive symptoms and sleep difficulty in a Japanese sample. Springer Plus, 5, Article 712. https://doi.org/10.1186/ s40064-016-2393-0

Levin, M. E., Luoma, J. B., Vilardaga, R., Lillis, J., Nobles, R., \&Hayes, S. C. (2016). Examining the role of psychological inflexibility, perspective taking, and empathic concern in generalized prejudice. Journal of Applied Social Psychology, 46(3), 180 191. https://doi.org/10.1111/jasp.12355

Lovibond, P. F., \& Lovibond, S. H. (1995). The structure of negative emotional states: Comparison of the Depression Anxiety Stress Scales (DASS) with the Beck Depression and Anxiety Inventories. Behaviour Research and Therapy, 33(3), 335-343. https://doi.org/10.1016/0005-7967(94)00075-U

Masuda, A., \& Tully, E. C. (2012). The role of mindfulness and psychological flexibility in somatization, depression, anxiety, and general psychological distress in a nonclinical college sample. Journal of Evidence-Based Complementary \& Alternative Medicine, 17(1), 66-71. https://doi.org/10.1177/2156587211423400

Masuda, A., Price, M., Anderson, P. L., \& Wendell, J. W. (2010). Disordered eating-related cognition and psychological flexibility as predictors of psychological health among college students. Behavior Modification, 34(1), 3-15. https://doi.org/10.1177/0145445509351569

McCracken, L. M., \&Gauntlett-Gilbert, J. (2011). Role of psychological flexibility in parents of adolescents with chronicpain: Developmentof a measure and preliminary correlation analyses. PAIN, 152(4), 780—785. https://doi.org/10.1016/j. pain.2010.12.001

Mirović, T., \& Mešković, D. (2017). Explaining Early Maladaptive Schemas (EMS): Connections between Basic Personality Dimensions, Affective Attachment Styles and Empathy. In A. Columbus (Ed.). Advances in Psychology Research (45-83). Nova. SciencePublishers.

Mirović, T. (2015). Shema terapija. U Vukosavljević-Gvozden (Ur.). Kognitivno-bihejvioralne terapije danas $(101-125)$. Institut za psihologiju.

Mirović, T. (2010). Sheme koje prave probleme. Zadužbina Andrejević. 
Pepping, C. A., \& Duvenage, M. (2016). The origins of individual differences in dispositional mindfulness. Personality and Individual Differences, 93, 130-136. https://doi.org/10.1016/j.paid.2015.05.027

Rezaei, M., \& Ghazanfari, F. (2016). The role ofchildhood trauma, early maladaptive schemas, emotional schemas and experimental avoidance on depression: A structural equation modelling. Psychiatry Research, 246, 407-414. https://doi.org/10.1016/j. psychres.2016.10.037

Roediger, E., Stevens, B. A., \& Brockman, R. (2018). Contextual schema therapy: An integrative approach to personality disorders, emotional dysregulation, and interpersonal functioning. New Harbinger Publications.

Thimm, J. C. (2017). Relationships between early maladaptive schemas, mindfulness, self-compassion, and psychological distress. International Journal of Psychology and Psychological Therapy, 17(1), 3-17.

Van Vreeswijk, M., Broersen, J., \& Schurink, G. (2014). Mindfulness and schema therapy: A practical guide. John Wiley\&Sons.

Wersebe, H., Lieb, R., Meyer, A. H., Hofer, P., \& Gloster, A. T. (2018). The link between stress, well-being, and psychological flexibility during an acceptance and commitment therapy self-help intervention. International Journal of Clinical and Health Psychology, 18(1), 60-68. https://doi.org/10.1016/j.ijchp.2017.09.002

Williams, K. E., Ciarrochi, J., \& Heaven, P. C. L. (2012). Inflexible parents, inflexible kids: A 6-year longitudinal study of parenting style and the development of psychological flexibility in adolescents. Journal of Youth and Adolescence, 41(8), 1053-1066. https://doi.org/10.1007/s10964-012-9744-0

Yadavaia, J. E., Hayes, S. C., \& Vilardaga, R. (2014). Using acceptance and commitment therapy to increase self-compassion: A randomized controlled trial. Journal of contextual behavioural science, 3(4), 248 - 257. https://doi.org/10.1016/j.jcbs.2014.09.002

Young, J. E., \& Brown, G. (2005). Young schema questionnaire-Short form; Version 3 (YSQ-S3, YSQ) [Database record]. APA PsycTests. https://doi.org/10.1037/t67023000

Young, J.E., Klosko, J.S., \&Weishaar, M. (2003). Schema Therapy: A Practitioner's Guide. The Guilford Press.

Young, J.E. (1990). Cognitive therapy for personality disorders: A schema-focused approach. Professional ResourcePress.

Young, J.E. (1993). The Schema Diary. Cognitive Therapy Center of New York.

Žuljević, D., Rakočević, N., \& Krnetić, I. (2020). Testing the model of psychological flexibility in the Serbian cultural context: The psychometric properties of the acceptance and action questionnaire. Psihologija, 53 (2), 161-181. https://doi.org/10.2298/ PSI191015006Z 
Igor Krnetić ${ }^{2}$

Faculty of Philosophy

University of Banja Luka

Republic of Srpska, Bosnia and Herzegovina

\title{
Lana Vujaković
}

Faculty of Philosophy

University of Banja Luka

Republic of Srpska, Bosnia and Herzegovina

\section{PSYCHOLOGICAL FLEXIBILITY AS A MEDIATOR OF THE RE- LATIONSHIP BETWEEN EARLY MALADAPTIVE SCHEMAS AND MANIFESTATIONS OF DEPRESSION, ANXIETY AND STRESS}

\begin{abstract}
Although the link between Early Maladaptive Schemas and many psychopathological manifestations has been confirmed, there is still not enough research examining the mechanism by which this link is realized. The aim of this study was to examine whether psychological inflexibility could be a mediator of the relationship between early maladaptive schemas grouped in schema domains and problems in current functioning, manifested through depression, anxiety and stress symptoms. Among the instruments used were the Young's Schema Questionnaire, the Acceptance and Action Questionnaire and Depression, Anxiety, and Stress Scales. The sample included 320 subjects $\left(N_{\text {females }}=215 ; M=33.5 ; S D=9.6\right)$. The results indicate significant connections of psychological inflexibility with all scheme domains and all criterion variables, with this connection being the strongest in relation to depression $(r=.74$, $p<.01)$ and autonomy impairment domain $(r=.74, p<.01)$. Schema domains are important predictors of criterion variables, provided that the highest percentage of explained variance is in relation to depression. Psychological inflexibility has been shown to be a partial mediator of all relations between all schema domains and manifestations of depression, anxiety and stress. Although schema domains still have a significant direct effect on psychopathological manifestations, in the case of impaired limits when it comes to anxiety $(b=.045 ; \mathrm{p}<.05,95 \%$ $\mathrm{BCa}$ CI $[.03, .05])$ and depression $(b=.06, \mathrm{p}<.05,95 \% \mathrm{BCa}$ CI $[.04, .07])$ the difference between the indirect and direct effect is most evident, while in the case of stress the greatest difference between the effects is in relation to the domain of autonomy impairment $(b=.07$, $\mathrm{p}<.05,95 \% \mathrm{BCa}$ CI $[.05, .08])$. The implications for the integration of schema therapy and third wave cognitive-behavioral therapy are discussed.
\end{abstract}

Keywords: early maladaptive schemas, schema domains, psychological flexibility, depression, stress, anxiety

Primljeno: 08.07.2021.

Primljena korekcija: 06.10.2021.

Prihvaćeno za objavljivanje: 27.10.2021.

\footnotetext{
${ }^{2}$ igor.krnetic@ff.unibl.org

Please cite as: Krnetić, I., \& Vukajović, L. (2021). Psihološka nefleksibilnost kao medijator odnosa između ranih maladaptivnih shema i manifestacija depresivnosti, anksioznosti i stresa [Psychological flexibility as a mediator of the relationship between early maladaptive schemas and manifestations of depression, anxiety and stress]. Godišnjak za psihologiju, 18, 09-25. https://doi.org/10.46630/gpsi.18.2021.01
} 